\title{
What Are the Real Roles of Different ErbB Proteins in Barrett's Esophagus
}

\author{
Tsutomu Chiba \\ Department of Gastroenterology and Hepatology, Graduate School of Medicine, Kyoto University, Kyoto, Japan
}

The erbB family of receptor tyrosine kinases includes four homologous proteins: the epidermal growth factor (EGF) receptor and erbB2, -3 , and -4 . These erbB receptors regulate proliferation, differentiation, migration, cell survival or apoptosis through a complex signaling pathway [1, 2]. In human malignant tissue, overexpression of the erbB receptors and/or amplification of their genes are frequent. Among them, EGF receptor is widely distributed throughout the gastrointestinal epithelium. EGF peptides, including transforming growth factor- $\alpha$ (TGF- $\alpha$ ), heparin-binding EGF-like growth factor and amphiregulin, activate the tyrosine kinase of the EGF receptor. These peptides are known to exert a variety of effects through EGF receptor on gastrointestinal tract such as stimulation of epithelial cell proliferation and migration, control of acid and mucus secretion, increase of gastric blood flow, stimulation of intestinal $\mathrm{NaCl}$ absorption and $\mathrm{Na}^{+} / \mathrm{H}^{+}$exchange [3]. Binding of EGF peptides to EGF receptor forms noncovalent heterodimeric complexes of the EGF receptor with erbB2, which enhances EGF receptor signaling. However, erbB2 overexpression results in production of its ligandindependent homodimeric complexes, followed by the enhancement of its signal transduction pathways [4]. In approximately $20-30 \%$ of breast cancers, overexpression of erbB2 has been identified. High levels of erbB2 expression are associated with accelerated tumor progression and metastatic activity. Thus, erbB2 expression levels are considered to be well-characterized indicators of prognosis in patients with breast cancer [5]. Furthermore, erbB2 is now a target of novel breast cancer treatments with trastuzu- mab (Herceptin), monoclonal antibodies against erbB2. Expression of erbB2 has also been detected in intestinal and colonic epithelia and gastrointestinal cancers [6-8]. Amplification of the erbB2 gene or overexpression of the erbB2 protein has also been reported in gastric adenocarcinoma, correlating with metastasis and survival [9]. In contrast to other erbBs, erbB3 lacks intrinsic tyrosine kinase activity [10]. Therefore, its heterodimer formation with erbB2 is necessary for erbB3 phosphorylation. ErbB3 is found in epithelial cells throughout the digestive tract [11]. In colon cancer, both erbB2 and erbB3 expression levels were higher than in normal mucosa [12]. Heregulin (HRG)/neuregulin isoforms have been identified as erbB3 ligands. Accumulating evidence suggests that regulation of the HRG/erbB2/erbB3 pathway may play an important role in tumor growth of the colon [13]. ErbB4 is also a receptor for HRG. Some studies suggest that erbB4 may contribute to the growth of gastric cancer [14].

Recently, the incidence of Barrett's esophagus-associated adenocarcinoma is increasing in Western countries. In previous studies, EGF receptor and TGF- $\alpha$ have been shown to be increased in dysplastic lesions of the esophagus and in esophageal adenocarcinoma. In esophageal adenocarcinoma, EGF receptor and TGF- $\alpha$ expressions are associated with poor patient survival and metastases [15, 16]. On the other hand, quite a wide range of percentages of erbB2 overexpression have been reported in esophageal adenocarcinoma, ranging from 10 to $73 \%$ [17]. Nakamura et al. [18] studied 80 cases of Barrett's esophagus-associated adenocarcinoma and found a significant correlation

\section{KARGER \\ Fax +4161306 1234 \\ E-Mail karger@karger.ch \\ www.karger.com \\ (c) 2004 S. Karger AG, Basel \\ 0012-2823/04/0702-0093\$21.00/0 \\ Accessible online at: \\ www. karger.com/dig}

Tsutomu Chiba

Department of Gastroenterology and Hepatology

Graduate School of Medicine, Kyoto University

Kyoto 606-8507 (Japan)

Tel. +81 75751 4302, Fax +81 75751 4303, E-Mail chiba@kuhp.kyoto-u.ac.jp 
between erbB2 overexpression and increasing depth of invasion, lymph node metastasis, and distant organ metastasis. Although conflicting data are present, some studies suggest that erbB2 overexpression may also be an independent predictor of poor prognosis [9, 17].

In this issue of Digestion, Nishigaki et al. [19] examined expression levels of EGF receptor, erbB2, and erbB3 in specialized columnar epithelium (SCE) of Barrett's esophagus, and found that EGF receptor and erbB2 are strongly expressed in both SCE and squamous epithelium, whereas erbB3 expression is limited to the squamous epithelium. The author's method using chromoendoscopy with methylene blue to identify SCE is safe and relatively inexpensive, and can easily distinguish between metaplastic and gastric type columnar epithelium of Barrett's esophagus. Therefore, their method with methylene blue is recommended to investigate Barrett's epithelium. From their data, they suggested that erbB2 might be involved in the metaplasia-dysplasia-carcinoma sequence at stages earlier than previously expected. Although there have been many studies showing the relationship between erbB2 and Barrett's esophagus-associated adenocarcinoma, their study is the first to report a different expression pattern of erbB3 in squamous epithelium and SCE of the esophagus. Their results may suggest that in addition to erbB2, erbB3 has an important role in epithelial cell differentiation and proliferation in the esophagus under physiological conditions rather than pathological conditions. The authors have already shown in a previous study the involvement of HRG in the growth of normal gastric epithelia through erbB3 [20]. Therefore, to elucidate the exact role of erbB3 in squamous epithelium, they might as well examine the involvement of HRG in esophageal function such as epithelial cell differentiation and proliferation. In any case, it is of great interest that erbB3 expression in SCE decreased considerably compared to that in esophageal squamous epithelium. These results may suggest that loss of erbB3 signaling in SCE trigger the dysplasia-carcinoma sequence in esophageal epithelium. In order to support such an idea, expression of erbB3 should be examined in SCE with dysplastic changes and esophageal adenocarcinoma. On the other hand, pathophysiological significance of loss of erbB3 expression in SCE is unknown at present. However, as discussed by Nishigaki et al. [19] in their report, it may be interesting to speculate that loss of erbB3 enhances erbB2 homodimerization with resulting augmentation of erbB2 signaling pathway.

\section{References}

1 Olayioye MA, Neve RM, Lane HA, Hynes NE: The ErbB signaling network: Receptor heterodimerization in development and cancer. EMBO J 2000;19:3159-3167.

2 Yarden Y, Sliwkowski MX: Untangling the ErbB signalling network. Nat Rev Mol Cell Biol 2001;2:127-137.

3 Uribe JM, Barrett KE: Nonmitogenic actions of growth factors: An integrated view of their role in intestinal physiology and pathophysiology. Gastroenterology 1997;112:255-268.

4 Tzahar E, Waterman H, Chen X, Levkowitz G, Karunagaran D, Lavi S, Ratzkin BJ, Yarden Y: A hierarchical network of interreceptor interactions determines signal transduction by $\mathrm{Neu}$ differentiation factor/neuregulin and epidermal growth factor. Mol Cell Biol 1996;16: 5276-5287.

5 Rubin I, Yarden Y: The basic biology of HER2. Ann Oncol 2001;12(suppl 1):3-8.

6 Quirke P, Pickles A, Tuzi NL, Mohamdee O, Gullick WJ: Pattern of expression of c-erbB-2 oncoprotein in human fetuses. $\mathrm{Br} \mathrm{J}$ Cancer 1989;60:64-69.

7 Tsujino T, Yoshida K, Nakayama H, Ito $\mathrm{H}$, Shimosato T, Tahara E: Alterations of oncogenes in metastatic tumours of human gastric carcinomas. Br J Cancer 1990;62:226-230.

8 Jankowski J, Coghill G, Hopwood D, Wormsley KG: Oncogenes and onco-suppressor gene in adenocarcinoma of the oesophagus. Gut 1992;33:1033-1038.
9 Ross JS, McKenna BJ: The HER-2/neu oncogene in tumors of the gastrointestinal tract. Cancer Invest 2001; 19:554-568.

10 Guy PM, Platko JV, Cantley LC, Cerione RA, Carraway KL 3rd: Insect cell-expressed p180erbB3 possesses an impaired tyrosine kinase activity. Proc Natl Acad Sci USA 1994;91: 8132-8136.

11 Prigent SA, Lemoine NR, Hughes CM, Plowman GD, Selden C, Gullick WJ: Expression of the c-erbB-3 protein in normal human adult and fetal tissues. Oncogene 1992;7:12731278.

12 Maurer CA, Friess H, Kretschmann B, Zimmermann A, Stauffer A, Baer HU, Korc M, Büchler MW: Increased expression of erbB3 in colorectal cancer is associated with concomitant increase in the level of erbB2. Hum Pathol. 1998;29:771-777.

13 Venkateswarlu S, Dawson DM, St Clair P, Gupta A, Willson JK, Brattain MG: Autocrine heregulin generates growth factor independence and blocks apoptosis in colon cancer cells. Oncogene 2002;21:78-86.

14 Kataoka H, Joh T, Kasugai K, Okayama N, Moriyama A, Asai K, Kato T: Expression of mRNA for heregulin and its receptor, ErbB-3 and ErbB-4, in human upper gastrointestinal mucosa. Life Sci 1998;63:553-564.
15 Jankowski J: Altered gene expression of growth factors and their receptors during esophageal tumorigenesis. Gastroenterol Clin Biol 1994; 18:D40-D45.

16 Yacoub L, Goldman H, Odze RD: Transforming growth factor- $\alpha$, epidermal growth factor receptor, and MiB-1 expression in Barrett'sassociated neoplasia: Correlation with prognosis. Mod Pathol 1997;10:105-112.

17 Krishnadath KK, Reid BJ, Wang KK: Biomarkers in Barrett esophagus. Mayo Clin Proc 2001;76:438-446.

18 Nakamura T, Nekarda $H$, Hoelscher $\mathrm{AH}$, Bollschweiler E, Harbeck N, Becker K, Siewert JR, Harbeck N: Prognostic value of DNA ploidy and c-erbB-2 oncoprotein overexpression in adenocarcinoma of Barrett's esophagus. Cancer 1994;73:1785-1794.

19 Nishigaki H, Wada K, Tatsuguchi A, Sueoka N, Futagami S, Gudis K, Miyake K, Tsukui T, Sakamoto C: ErbB2 without erbB3 expression in metaplastic columnar epithelium of the Barrett's esophagus. Digestion 2004; 70:95-102.

20 Noguchi H, Sakamoto C, Wada K, Akamatsu T, Uchida T, Tatsuguchi A, Matsui H, Fukui H, Fujimori T, Kasuga M: Expression of heregulin $\alpha$, erbB2, and erbB3 and their influences on proliferation of gastric epithelial cells. Gastroenterology 1999;117:1119-1127. 